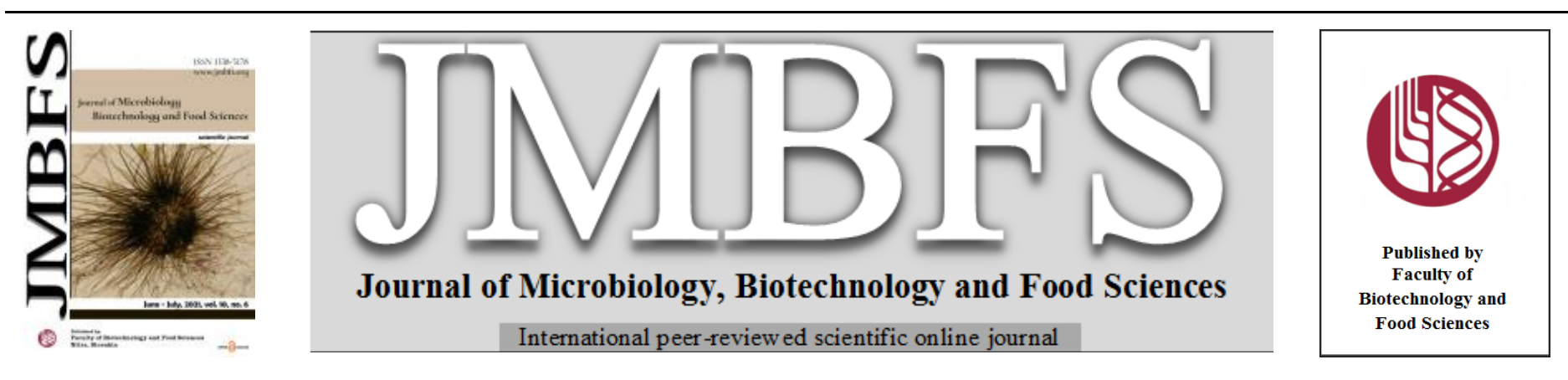

\title{
RESPONSE OF CADAVERINE ON THE PROTEIN PROFILING OF CULTURED TISSUES OF BRASSICA JUNCEA (RH-30) UNDER MULTIPLE STRESS
}

\author{
Pushpa C. Tomar* ${ }^{1}$ and Komal Arora ${ }^{l}$ \\ $\operatorname{Address(es):~}$ \\ Department of Biotechnology Engineering, Faculty of Engineering \& Technology, Manav Rachna International Institute of Research and Studies, Faridabad, Haryana, \\ (INDIA) - 121004
}

*Corresponding author: pushpa.fet@mriu.edu.in

https://doi.org/10.15414/jmbfs.4002

\section{ARTICLE INFO}

Received 24. 11. 2020

Revised 3. 1. 2021

Accepted 8. 1. 2021

Published 1. 6. 2021

Regular article

OPEN $\partial_{\text {ACCESS }}$

\begin{abstract}
A lysine catabolite named cadaverine, a polyamine is known as plant growth regulating compound. Its precise role as growth regulators and/or inducer of nitrogen assimilation positively affects plant growth and productivity under different stress condition. Cad strongly maintains the stressed plant growth through maintaining the metabolites and ionic homeostasis. This entry summarizes not only cadaverine effect on B. juncea callus in terms of the growth parameters but also on protein content and profiling of these mustard calli. The basal medium used for tissue culture was MS media augmented with different stress conditions and treatments $(100 \mathrm{mM} \mathrm{NaCl}, 1 \mathrm{mM}$ $\mathrm{Cd}$ or $\mathrm{Pb}, 1 \mathrm{mM}$ cadaverine or $5 \mathrm{mM} \mathrm{NH}_{4} \mathrm{NO}_{3}$ ). Better growth was observed in callus grown in media supplemented with cad as compared to control and stressed one. Also, callus sub cultured in cad media maintained desired growth of callus over control and even with $\mathrm{NH}_{4} \mathrm{NO}_{3}$ supplementation. The application of Cad suppressed the accumulation of $66 \mathrm{kDa}$ peptide under salt stress whereas the same peptide's expression remained unaffected by $\mathrm{NH}_{4} \mathrm{NO}_{3}$ supplementation. $\mathrm{NH}_{4} \mathrm{NO}_{3}$ induced the expression of 54 and $44 \mathrm{kDa}$ peptides under $\mathrm{NaCl}$ and $\mathrm{Pb}$ stress. Sub- cultured callus upon $\mathrm{Cad}$ supplementation significantly expressed peptides of 76, 72, 45, 42, 40, $32,30,24,22$ and $21 \mathrm{kDa}$, where expression of 66 and $34 \mathrm{kDa}$ peptides were prominent. Cad boosted the callus formation and growth when grown in stressed conditions and these stress induced proteins in the presence of Cad suggesting their role in the growth of plant under various stress conditions.
\end{abstract}

Keywords: Brassica juncea; Cadaverine; Callus; Polyamines; Protein; Stress

\section{INTRODUCTION}

'Cadaver' derived word, Cadaverine is a lysine catabolite which is sometimes associated with decaying matter (foul odour of putrefying flesh of cadaver) and is one of the reasons and a component that gives carrion its distinctive smell. Cadaverine is known for its functions in multiple cellular processes critical to living organisms. This statement can be justified by following examples: acid stress responses in Escherichia coli mediated by cadaverine (Haneburger $\boldsymbol{e t}$ al., 2012), cadaverine's foul-smelling, unpleasant odour help animals to perform behavioural cues (Rolen et al., 2003; Hussain et al., 2013), its contribution in growth and development of plant, responses to stress conditions, cell signalling and insect defense. It is also involved in numerous activities such as it is a precursor of polyamides, its role in water absorption, it ensures the survival of cell in acidic conditions, protects cells that are starved of inorganic phosphate, $\mathrm{Pi}$, under anaerobic conditions, regulates animal growth (Ma et al., 2017; Moreau $\boldsymbol{e}$ al., 2007; Samartzidou et al., 2003; Andersson et al., 1979). Further, tolerance to crop salt, improvisation of heavy metal stress regulated by Cad (Rajpal and Tomar, 2020). The presence of enzyme LDC in higher plants specifically in plants belonging to family leguminoseae, gramineae and Solanaceae, bacteria indicate the wide presence of Cadaverine (Incharoensakdi et al., 2010; Bagni $\boldsymbol{e t}$ al., 1986; Rodríguez et al., 2000; Sempruch et al., 2010). Cadaverine is also present in the environment; it can be produced by rhizosphere and phyllosphere microbes (Jancewicz et al., 2016).

In order to maintain the healthy conditions either for plant strength or for crop production, it is crucial to manage these varied phenomena. Changes in the morphological characteristics have been reported in various species like Arabidopsis, rice, soybean and Scotspines upon changes in the concentration of cadaverine within a plant. the reason of concentration change may be due to environmental encouragement of synthesis or through exposure to exogenous cadaverine (Gamarnik and Frydman, 1991; Niemi et al., 2002; Cassánetal, 2009; Campestre et al., 2011; Liu et al., 2014; Strohm et al., 2015). There are some previous studies being done indicating cadaverine's effect on mustard seedlings (Brassica juncea) and the response of the seedlings prove to be protective for them was recorded. (Tomar et al., 2013a, b)

Brassica juncea, a good bee plant, whose seeds after cultivation, yielding essential oil. It is a plant with intensive flavouring and healing properties (Fomina, 1962). In some studies, B. juncea has been known for its biodiesel potential also (Jham et al., 2009). The effect of cadaverine has been explored on seedlings of Brassica juncea in terms of growth and biochemical parameters (Tomar et al., 2013a, b). Here cadaverine has shown its great protective action on the seedlings as mentioned above. However, cadaverine's role in responses to stress conditions facing some contradictions due the fact that its presence leads to tolerance to stress responses in some plants whereas in others, presence of cadaverine leads to sensitivity to the same stress responses.

In present study, effect of cadaverine is been studied on the callus of Brassica juncea and the response of the effects has been recorded and gathered. Therefore, this study will provide some insight to understand it's some regulatory mechanism in plants growth and its potential to mitigate the adverse responses induced under multiple stresses, generally realized by plants in field condition in compare to its response with $\mathrm{NH}_{4} \mathrm{NO}_{3}$.

\section{MATERIAL AND METHODS}

\section{Growth parameters}

Seeds sampling was done base $\mathrm{d}$ on uniformity in size and similarity in morphology. Selected seeds were sterilized for 1 minute by $70 \%$ alcohol followed by 5 minutes sterilization by $0.2 \%$ mercuric chloride. Sterilized seeds, before planting, thoroughly washed 5-6 times by distilled water and cultured in MS media as given by Murashige and Skoog, 1962 (Murashige and Skoog, 1962). The constituents of basal medium were sucrose $(3 \%)$, agar-agar $(0.7 \%)$ with $100 \mathrm{mM} \mathrm{NaCl}, 1 \mathrm{mM} \mathrm{Cd} / \mathrm{Pb}$, autoclaved (sterilized) $1 \mathrm{mM}$ cadaverine and $5 \mathrm{mM} \mathrm{NH}_{4} \mathrm{NO}_{3}$. Nutrient solution's $\mathrm{pH}$ in all conditions of treatments was maintained at 5.8 (slightly acidic). Following a week, hypocotyl region of the sterilized seedling (explant) was excised and cultured in MS media augmented 
with $2.0 \mathrm{mg} / \mathrm{ml} \mathrm{BAP}$ and $0.2 \mathrm{mg} / \mathrm{ml} \mathrm{NAA} \mathrm{(growth} \mathrm{hormones)} \mathrm{and} \mathrm{different} \mathrm{stress}$ treatments, followed by 3 weeks incubation at $25^{\circ} \mathrm{C} \pm 2^{\circ} \mathrm{C}$ and $65 \% \mathrm{RH}$ resulting in callus formation. The subpart of the callus was taken and kept for the incubation again, in the conditions mentioned above. The callus thus formed was then undergone a protein profiling to determine the protein content and level under multiple stress and treatments.

\section{Protein content and profiling}

Lowry method was used to estimate the total soluble protein in samples (Lowry et al., 1951). The polypeptides profile was examined through SDS-PAGE (12.5\%) following Laemmli, 1970 (Laemmli, 1970) Standard protein markers were used for characterization of molecular weight. The data given are mean value of at least three replicates with $\pm \mathrm{SD}$.

\section{RESULTS AND DISCUSSION}

\section{Growth parameters}

Seed germination was done in MS media included with either $\mathrm{NaCl}$ or $\mathrm{Pb}$ or $\mathrm{Cc}$ with $\mathrm{NH}_{4} \mathrm{NO}_{3}$ or Cad (Plate 1). Varied responses have been shown by cadaverine during callus and sub cultured phase of growth (Plate 2,3). MS media augmented with BAP and NAA in appropriate concentrations together with cadaverine for the desired (better) growth. The two-fold increase in callus was found upon inclusion of Cad in MS medium (Plate 1). Low germination was observed under salt stressed callus in the presence and absence of Cad. Cd stressed callus showed 92\% same seed germination as in other conditions, however, poor growth of the seedlings was observed even after $\mathrm{Cad} / \mathrm{NH}_{4} \mathrm{NO}_{3}$ supplementation suggested not to execute any further experiments with this in vitro (Plate 1). Sub-cultured callus of 4 weeks treated with $\mathrm{NH}_{4} \mathrm{NO}_{3}$ and $\mathrm{Cad}$ showed maximum growth (Plate 3 ).

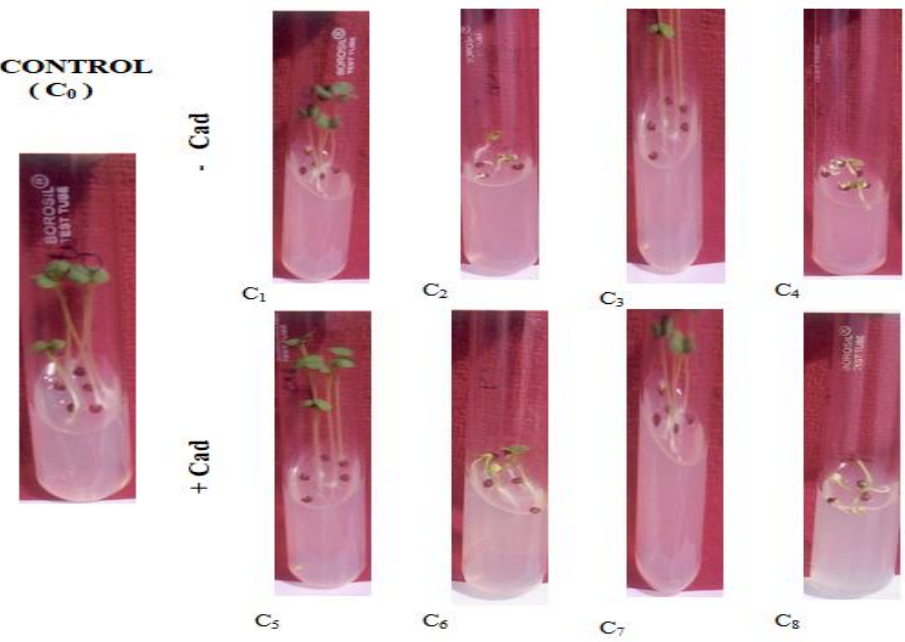

Plate 1 Seedling germination on MS media augmented with stresses (metal and salt) and treatments $\left(\mathrm{NH}_{4} \mathrm{NO}_{3}\right)$
$\mathrm{C}_{0}$ - Control
$\mathrm{C}_{1}-\mathrm{NH}_{4} \mathrm{NO}_{3}(5 \mathrm{mM})$
$\mathrm{C}_{2}-\mathrm{NH}_{4} \mathrm{NO}_{3}+\mathrm{NaCl}(100 \mathrm{mM})$
$\mathrm{C}_{3}-\mathrm{NH}_{4} \mathrm{NO}_{3}+\mathrm{Pb}(1 \mathrm{mM})$
$\mathrm{C}_{5}-\mathrm{Cad}(1 \mathrm{mM})$
$\mathrm{C}_{6}-\mathrm{Cad}+\mathrm{NaCl}$
$\mathrm{C}_{7}-\mathrm{Cad}+\mathrm{Pb}$
$\mathrm{C}_{8}-\mathrm{Cad}+\mathrm{Cd}$

$\mathrm{C}_{4}-\mathrm{NH}_{4} \mathrm{NO}_{3}+\mathrm{Cd}(1 \mathrm{mM})$

Cd stressed condition resulted in a poor growth of seedling and hence we discontinued the further experiments with $\mathrm{Cd}$.
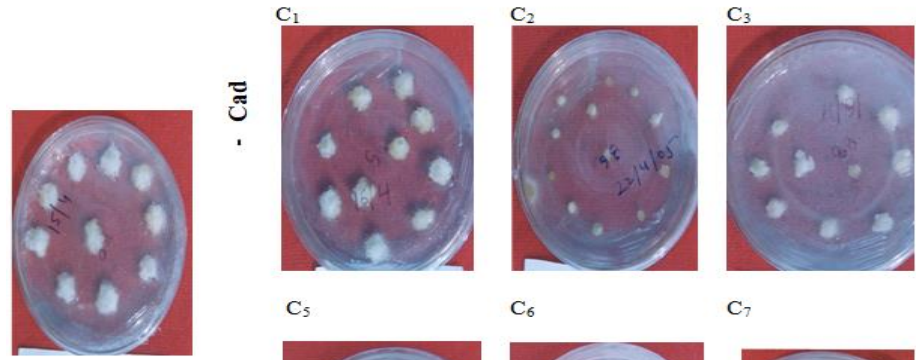

$\mathrm{C}_{5}$

$\mathrm{C}_{6}$

$\mathrm{C}_{7}$
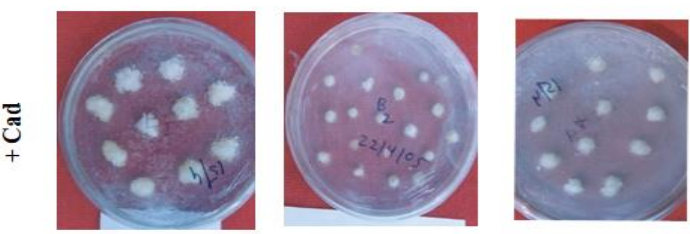

Plate 2 Formation of callus from hypocotyl region of explant following 3 weeks incubation (Legend is same as Plate 1)

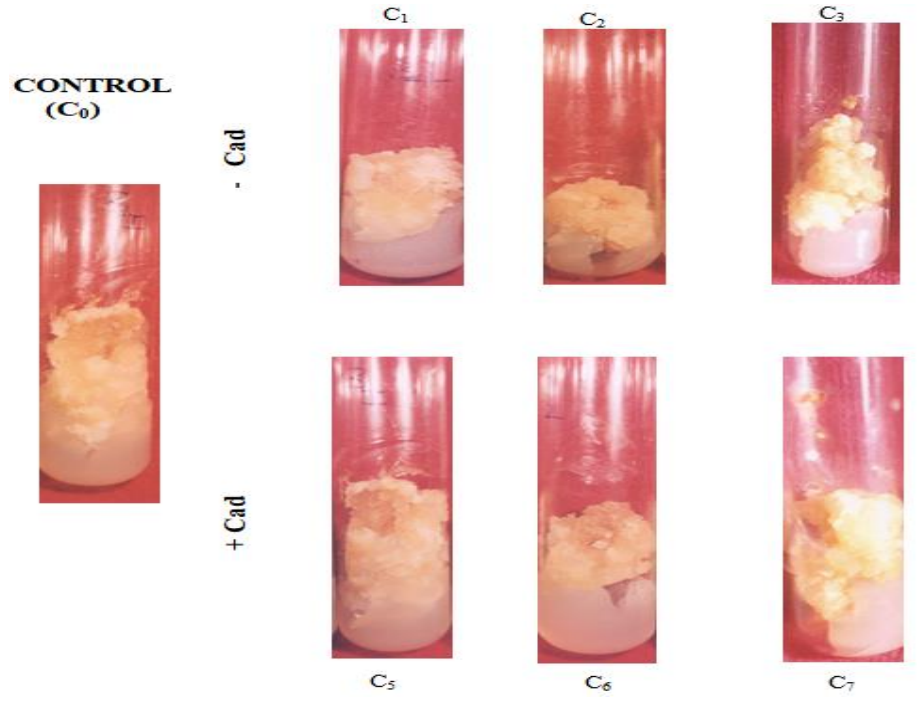

Plate 3 Callus following sub culturing for 4 weeks

(Legend is same as Plate 1)

Level of protein in the callus under stress in the presence and absence of cadaverine

For the protein level examination, 3 weeks cultured and 4 weeks sub cultured callus was taken. Significant increase in protein content was observed upon $\mathrm{NH}_{4} \mathrm{NO}_{3}$ supplementation as compared to control (Figure 1a). However, the same protein level not able to sustain under salt and $\mathrm{Pb}$ stressed conditions. Augmenting cad in salt stressed callus showed remarkable increase in the protein level and quite more under $\mathrm{Pb}$ stress as compared to supplementation of $\mathrm{NH}_{4} \mathrm{NO}_{3}$. Alteration in protein content was observed when protein content was evaluated after 21 days of sub- cultured callus (Figure $1 \mathrm{~b}$ ). $\mathrm{NH}_{4} \mathrm{NO}_{3}$ that showed inhibitory effect on accumulated protein in sub- cultured callus, exhibited the protective effect under $\mathrm{NaCl}$ or $\mathrm{Pb}$ stress on accumulated protein. Protein content was induced by cad in $\mathrm{NaCl}$ stressed callus and in $\mathrm{Pb}$ stressed callus, protein content was maintained to the initial level.

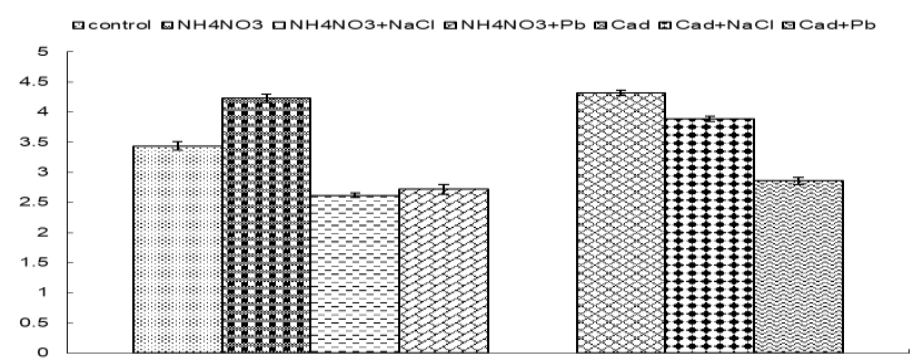

a

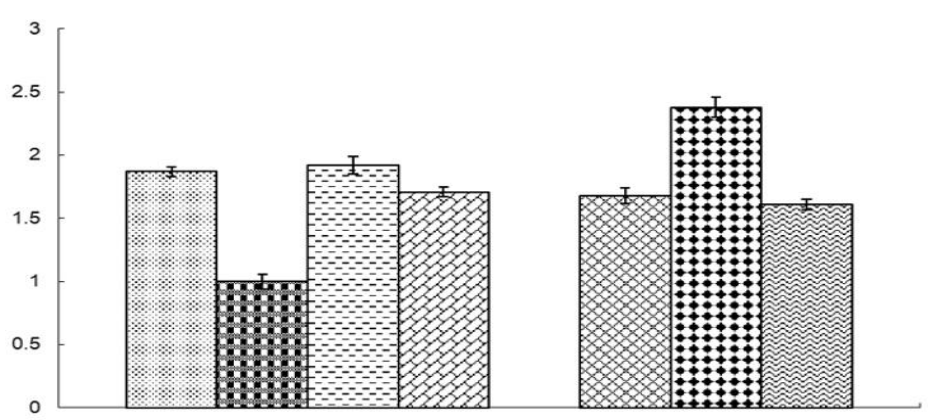

TREATMENTS

Figure 1 Level of protein in callus supplemented with $\mathrm{NH}_{4} \mathrm{NO}_{3}$ and $\mathrm{Cad}$ (a) Protein level in sub cultured callus

(b) Protein level in callus obtained from explant of mustard seedlings.

Data are mean value of replicas with $(n=3) \pm$ SD. Asterisks indicate the significance of difference at $\mathrm{p}<0.05 \%(*)$ probably significant, $\mathrm{p}<0.01(* *)$ definitely significant, $\mathrm{p}<0.001$ (***) highly significant and No asterisks indicate insignificant $\mathrm{p}>=0.05$. Comparison between two nitrogenous sources were indicated by $\mathrm{p}<0.05 \%$ (c) probably significant, $\mathrm{p}<0.01$ (b) definitely significant, $\mathrm{p}<0.001$ (a) highly significant and No symbol indicate insignificant $\mathrm{p}>=0.05$. 


\section{Callus' protein profile in presence and absence of Cadaverine under stress}

Study of callus' profile was done for comparison between callus and other plan tissues. A total of 11 bands observed (Figure 2, Table 1), some of which varied due to treatments. 95 and $88 \mathrm{kDa}$ bands were appeared in all kind of treatments. Cad suppressed the expression of the proteins caused by metal stress. No peptide of 66 and $76 \mathrm{kDa}$ observed in callus of normal medium and the callus supplemented with $\mathrm{NH}_{4} \mathrm{NO}_{3}$. However, in stress conditions (not supplemented with $\mathrm{NH}_{4} \mathrm{NO}_{3}$ and cad), the expression of these peptides noticed. Upon application of $\mathrm{Cad}$, expression of $66 \mathrm{kDa}$ peptide was suppressed by $\mathrm{NaCl}$ whereas the same peptide's expression remained unaffected by $\mathrm{NH}_{4} \mathrm{NO}_{3}$ supplementation. The $\mathrm{NH}_{4} \mathrm{NO}_{3}$ had little more induction of 54 ad $44 \mathrm{kDa}$ under salinity/Pb stress (Figure 2, Table 1). $\mathrm{NH}_{4} \mathrm{NO}_{3}$ supplementation to salt and lead stressed callus downregulated the expression of $20 \mathrm{kDa}$ peptide. The cad under saline conditions suppressed the peptide of $27.5 \mathrm{kDa}$ which was present consistently in callus.

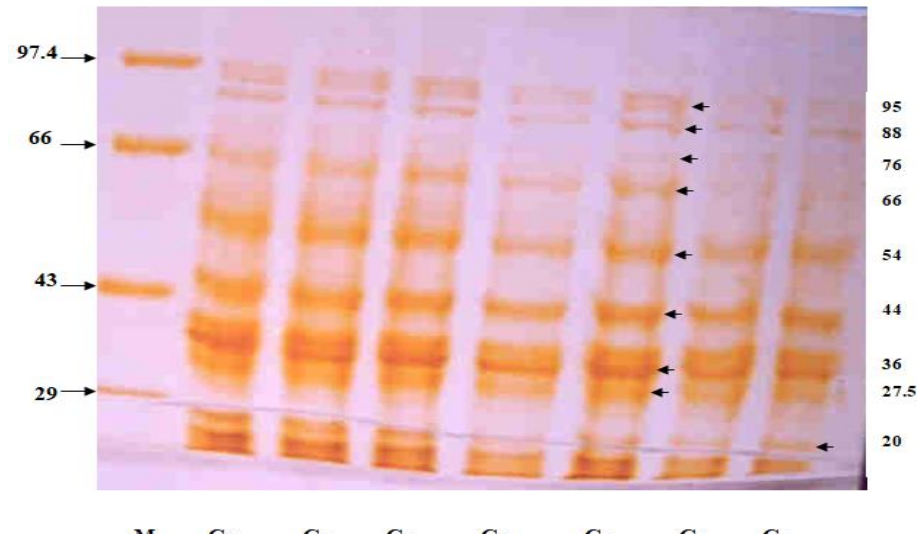

$\begin{array}{llllllll}\mathbf{M} & \mathrm{C}_{0} & \mathrm{C}_{1} & \mathrm{C}_{2} & \mathrm{C}_{3} & \mathrm{C}_{5} & \mathrm{C}_{6} & \mathrm{C}_{7}\end{array}$

Figure 2 Callus' protein profile in the presence and absence of Cad under stress following 3 weeks (Legend is same as Plate 1)

Table 1 Protein profile of Callus in the presence and absence of Cad under stress after 3 weeks

\begin{tabular}{lccccccc}
\hline $\mathbf{M}$ & $\mathbf{C}_{\mathbf{0}}$ & $\mathbf{C}_{\mathbf{1}}$ & $\mathbf{C}_{2}$ & $\mathbf{C}_{\mathbf{3}}$ & $\mathbf{C}_{\mathbf{5}}$ & $\mathbf{C}_{\mathbf{6}}$ & $\mathbf{C}_{7}$ \\
\hline $\mathbf{9 5}$ & + & ++ & ++ & + & + & + & + \\
\hline $\mathbf{8 8}$ & + & + & ++ & ++ & ++ & + & ++ \\
\hline $\mathbf{7 6}$ & - & - & + & + & + & + & + \\
\hline $\mathbf{6 6}$ & - & - & + & ++ & ++ & - & ++ \\
\hline $\mathbf{5 4}$ & ++ & ++ & +++ & +++ & ++ & + & ++ \\
\hline $\mathbf{4 4}$ & ++ & ++ & +++ & +++ & ++ & + & ++ \\
\hline $\mathbf{3 8}$ & ++ & ++ & ++ & ++ & ++ & + & ++ \\
\hline $\mathbf{3 6}$ & ++ & ++ & ++ & ++ & ++ & + & + \\
\hline $\mathbf{2 7 . 5}$ & + & + & + & + & + & - & + \\
\hline $\mathbf{2 5 . 8}$ & + & + & + & + & + & + & + \\
\hline $\mathbf{2 0}$ & + & + & - & - & - & - & + \\
\hline
\end{tabular}

M- Marker, $\mathrm{C}_{3^{-}} \mathrm{NH}_{4} \mathrm{NO}_{3}+\mathrm{Pb}, \mathrm{C}_{0}-$ Control, $\mathrm{C}_{5}-\mathrm{Cad}, \mathrm{C}_{1^{-}} \mathrm{NH}_{4} \mathrm{NO}_{3}, \mathrm{C}_{6^{-}} \mathrm{Cad}+\mathrm{NaCl}, \quad \mathrm{C}_{2^{-}}$ $\mathrm{NH}_{4} \mathrm{NO}_{3}+\mathrm{NaCl}, \mathrm{C}_{7}-\mathrm{Cad}+\mathrm{Pb}$

+: Poor growth, ++: Average growth, +++: Good growth, -: No growth

Callus' protein profile following sub culturing in Presence and Absence of Cad under Stress Conditions

A total of 16 bands appeared in sub-cultured callus of 4 weeks (Figure 3; Table 2). Sub- cultured callus supplemented with $\mathrm{NH}_{4} \mathrm{NO}_{3}$ induced the expression of peptides of 84,58 and $26 \mathrm{kDa}$ over the callus growing only in MS medium (without any nitrogenous source). The expression of 45 and $42 \mathrm{kDa}$ peptides were also remarkable upon $\mathrm{NH}_{4} \mathrm{NO}_{3}$ supplementation. However, in salt stressed conditions, addition of $\mathrm{NH}_{4} \mathrm{NO}_{3}$ couldn't expressed protein of 84, 58 and $26 \mathrm{kDa}$. Also, 58, 54 and $30 \mathrm{kDa}$ protein's expression was downregulated by salt stressed conditions. No change (protective effect) was observed in the expression of 66 $\mathrm{kDa}$ upon supplementation of $\mathrm{NH}_{4} \mathrm{NO}_{3}$ in saline conditions. However, $\mathrm{NH}_{4} \mathrm{NO}_{3}$ presence in $\mathrm{Pd}$ stressed conditions inhibited the 84, 58 and $45 \mathrm{kDa}$ peptides' expression (lane $\mathrm{C} 3$ ). The $54 \mathrm{kDa}$ peptide whose expression affected under salinity, showed controlled expression level with $\mathrm{NH}_{4} \mathrm{NO}_{3}$. Under $\mathrm{Pb}$ stress, 21 $\mathrm{kDa}$ protein was also expressed little more (Figure 3; Table 2). Sub- cultured callus upon Cad supplementation significantly expressed peptides of 76, 72, 45, $42,40,32,30,24,22$ and $21 \mathrm{kDa}$, where expression of 66 and $34 \mathrm{kDa}$ peptides were prominent. Presence of Cad couldn't maintain the expression level of 76 , 72,66 , and $45 \mathrm{kDa}$ peptides that was inhibited due to salt stressed conditions. However, under $\mathrm{Pb}$ stressed callus, in the presence of Cad, expression of 84,76 ,
$72,66,58$ and $54 \mathrm{kDa}$ peptides were observed. Prominent peptides were found of $66,54,45,42,34,30$ and $26 \mathrm{kDa}$.

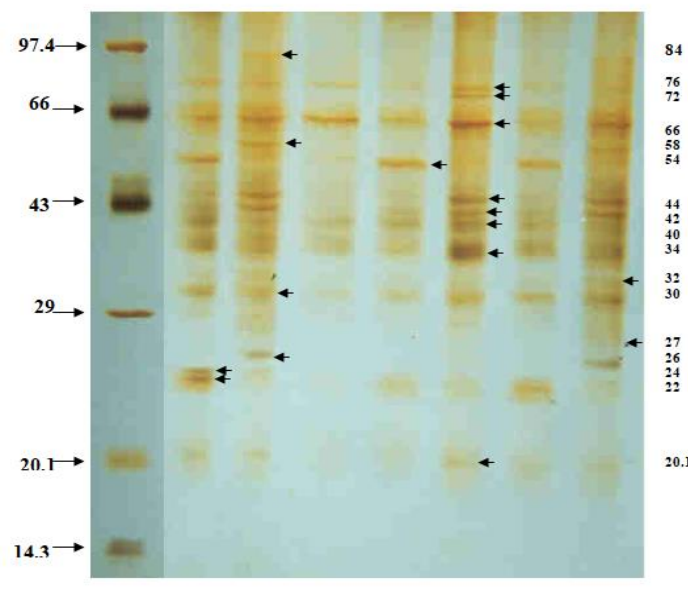

$\begin{array}{lllllllll}M & \mathrm{C}_{0} & \mathrm{C}_{1} & \mathrm{C}_{2} & \mathrm{C}_{3} & \mathrm{C}_{5} & \mathrm{C}_{6} & \mathrm{C}_{7}\end{array}$

Figure $3 \mathrm{Sub}$ cultured callus' protein profile in the presence and absence of $\mathrm{Cad}$ under stress following 4 weeks

(Legend is same as Plate 1 )

Table 2 Protein profile of sub-cultured callus in the presence and absence of Cad under stress after 4 weeks

\begin{tabular}{lccccccc}
\hline $\mathbf{M}$ & $\mathbf{C}_{\mathbf{0}}$ & $\mathbf{C}_{\mathbf{1}}$ & $\mathbf{C}_{2}$ & $\mathbf{C}_{\mathbf{3}}$ & $\mathbf{C}_{5}$ & $\mathbf{C}_{6}$ & $\mathbf{C}_{7}$ \\
\hline $\mathbf{8 4}$ & - & - & - & + & - & - & - \\
\hline $\mathbf{7 6}$ & - & + & + & + & + & + & + \\
\hline $\mathbf{6 6}$ & - & - & - & - & - & - & + \\
\hline $\mathbf{5 8}$ & + & + & ++ & ++ & ++ & + & ++ \\
\hline $\mathbf{5 4}$ & - & - & - & + & - & - & - \\
\hline $\mathbf{4 4}$ & - & - & ++ & - & - & ++ & - \\
\hline $\mathbf{4 2}$ & - & + & + & ++ & - & - & - \\
\hline $\mathbf{4 0}$ & - & + & + & ++ & - & + & + \\
\hline $\mathbf{3 4}$ & - & + & + & + & + & + & + \\
\hline $\mathbf{3 2}$ & ++ & ++ & + & + & +++ & + & + \\
\hline $\mathbf{3 0}$ & + & + & - & - & - & - & + \\
\hline $\mathbf{2 6}$ & ++ & ++ & + & + & ++ & ++ & ++ \\
\hline $\mathbf{2 4}$ & - & - & - & + & - & - & - \\
\hline $\mathbf{2 2}$ & - & + & + & + & - & - & - \\
\hline $\mathbf{2 0 . 1}$ & - & - & + & - & - & + & + \\
\hline & - & - & + & + & - & + & + \\
\hline
\end{tabular}

M- Marker, $\mathrm{C}_{3^{-}} \mathrm{NH}_{4} \mathrm{NO}_{3}+\mathrm{Pb}, \mathrm{C}_{0}-$ Control, $\mathrm{C}_{5}-\mathrm{Cad}, \mathrm{C}_{1^{-}} \mathrm{NH}_{4} \mathrm{NO}_{3}, \mathrm{C}_{6^{-}} \mathrm{Cad}+\mathrm{NaCl}, \mathrm{C}_{2^{-}}$ $\mathrm{NH}_{4} \mathrm{NO}_{3}+\mathrm{NaCl}, \mathrm{C}_{7}-\mathrm{Cad}+\mathrm{Pb}$

+: Poor growth, ++: Average growth, +++: Good growth, -: No growth

\section{DISCUSSION}

For the past decade, immense efforts have been made by researchers in order to develop biotechnology related methods for promoting rape breeding (Kott, 1998; Burbulis et al., 2004). Though in-depth research in the field of plant cell and tissue culture made us understand a lot about plant's physiology and morphology, still many mechanisms underlying the plant morphogenesis (in vitro) is not well known (Haibiao and Chong, 2004; Hurkman and Tanaka, 1987).

Data in tables 1,2 and figures 2 and 3 show the effect of treatments on the growth of callus. The diverse responses have been shown by cadaverine during callus and sub-cultured phase of growth. MS media augmented with BAP and NAA in appropriate concentrations together with cadaverine for the desired (better) growth. Small callus was formed in the explant treated with metal stress. Cd stressed callus showed $92 \%$ same seed germination as in other conditions, however, poor growth of the seedlings was observed even after $\mathrm{Cad} / \mathrm{NH}_{4} \mathrm{NO}_{3}$ supplementation suggested not to execute any further experiments with this in vitro (Plate 1). Hypocotyl region of the explant showed shoot formation (Plate 1, 2) in comparison with other studies (Khan et al., 2002). Oscar cultured hypocotyl explants of Brassica napus cv. on media supplemented with 2,4-D, shoot regeneration was induced sporadically. No shoot formation was observed on 2,4-D supplemented media as reported by Klimaszewska and Keller, 1985 (Klimaszewska and Keller, 1985). The reason being for the differences observed in their results and ours may be due to differential genotypes, or may be culturing explant (hypocotyls) in the medium free of hormone is critical to shoot formation. Zheng and Konzak, 1999 reported that media supplemented with 2,4- 
D showed callus induction in Triticum aestivum (Zheng and Konzak, 1999) However, 2,4-D concentration hindered further growth process and plant regeneration. The hypocotyls were used for callus generation (Plate 3-5). Callus grown from hypocotyl region of explant had better morphogenic ability (Chen $\boldsymbol{e}$ al., 1998). Less growth of callus was observed under salt and metal stress as compared to the control (Lima et al., 2003). Cad boosted the callus formation and growth when grown in stressed conditions by modifying the metabolites. Increment in the callus' protein content was also observed with Cad (Figure $1 \mathrm{a}$ b). Band of $54 \mathrm{kDa}$ protein was appeared in both- callus and sub-cultured callus (Figure 2; Table 1; Figure 3; Table 2). The same molecular weight bands of proteins (26 and $27 \mathrm{kDa}$ ) in salt-stressed barley roots (Hurkman and Tanaka 1987) have been found here in Brassica (Figure 3; Table 2).

Under salt stress, high expression of these proteins was found, suggesting the role in plant's survival during stress. Band of $26 \mathrm{kDa}$ protein observed in the cells of tobacco plant is salt adaptive/ resistant (Singh $\boldsymbol{e t}$ al., 1987). The presence of proteins of molecular weight 27 and $26 \mathrm{kDa}$ in the salt adapted cells of tobacco and rice; roots of barley indicating their contribution in (Shirata and Takagishi, 1990). Later stage disappearance of these proteins enables the salt tolerance mechanism of plant cells under saline stress by regulating gene expression. 95 and $88 \mathrm{kDa}$ proteins were highly expressed by Cad. Expression of 76, 72, 66, 45, 42, 40 and $34 \mathrm{kDa}$ peptides was induced by Cad in sub-cultured callus (Figure 2 Table 1; Figure 3; Table 2).

\section{CONCLUSION}

The study illustrated the cadaverine's precise role as growth regulators and/or inducer of nitrogen assimilation, hence effect on plant growth and productivity under stress condition. Cad strongly maintains the stressed plant growth through maintaining the metabolites and ionic homeostasis. This study will help in identifying new potentials in agricultural biotechnology considering the current scenario of soil infertility where biotic and abiotic stresses are the main cause of soil degradation and salinity and heavy metal pollution is a great threat to soil fertility. This also may provide some clue to Cadaverine presence other than leguminous crop plants, so far not reported.

\section{REFERENCES}

Andersson, A.C., Henningsson, S., \& Rosengren, E. (1979) Formation of cadaverine in the pregnant rat. Acta Physiol. Scand. 105(4), 508-512. https://doi:10.1111/j.1748-1716.1979.tb00115.x

Bagni, N., Creus, J., \& Pistocchi, R. (1986) Distribution of Cadaverine and Lysine Decarboxylase Activity in Nicotiana glauca Plants. J. Plant Physiol. 125(1-2), 9-15. https://doi:10.1016/s0176-1617(86)80238-3

Burbulis, N., Kupriene, R., Ûilenaite, L. (2004) Embryogenesis, callogenesis and plant regeneration from anther cultures of spring rape (Brassica napus L.). Acta Univ. Latv. Biol. 656, 153-158.

Campestre, M.P., Bordenave, C.D., Origone, A.C., Menéndez, A.B., Ruiz, O.A., Rodríguez, A.A., et al. (2011) Polyamine catabolism is involved in response to salt stress in soybean hypocotyls. J Plant Physiol. 168, 1234-1240. https://doi.org/10.1016/j.jplph.2011.01.007

Cassán, F., Maiale, S., Masciarelli, O., Vidal, A., Luna, V., Ruiz, O. (2009) Cadaverine production by Azospirillum brasilense and its possible role in plant growth promotion and osmotic stress mitigation. Eur J Soil Biol., 45, 12-19. https://doi.org/10.1016/j.ejsobi.2008.08.003

Fomina, Z.V. (1962) Weed plants of Buryatia and their control measures, UlanUde:Buryatskoye knizhnoye izdatelstvo. pp 17 (In Russian)

Gamarnik, A.A., Frydman, R.B.R. (1991) Cadaverine, an essential diamine for the normal root development of germinating soybean (Glycine max) seeds. Annu. Rev. Plant Biol. 97,778-785. https://doi.org/10.1104/pp.97.2.778

Haibiao, G., Chong, P.E. (2004) Identification and expression of genes associated with shoot regeneration from leaf disc explants of mustard (Brassica juncea) in vitro, Plant Sci. 167, 191-120. https://doi.org/10.1016/j.plantsci.2004.04.032

Haneburger, I., Fritz, G., Jurkschat, N., Tetsch, L., Eichinger, A., Skerra, A. Gerland, U., Jung, K. (2012) Deactivation of the E. coli pH stress sensor Cad C by cadaverine. J. Mol. Biol. 424, 15-27. https://doi.org/10.1016/j.jmb.2012.08.023

Hurkman, W.J., Tanaka, C.K. (1987) The effects of salt on the pattern of protein synthesis in barley roots. Plant Physiol. 83, 517-524. https://doi.org/10.1104/pp.83.3.517

Hussain, A., Saraiva, L.R., Ferrero, D.M., Ahuja, G., Krishna, V.S., Liberles, S.D., Korsching, I.S. (2013) High-affinity olfactory receptor for the deathassociated odor cadaverine. Proceedings of the National Academy of Sciences of the United States of America. 110, 19579-19584.

Chen, Y., Kenaschuk, E., Dribnenki, P. (1998) High frequency of plant regeneration from anther culture in flax, Linum usitatissimum L. Plant Breed. 117, 463-467. https://doi.org/10.1111/j.1439-0523.1998.tb01974.x

Incharoensakdi, A., Jantaro, S., Raksajit, W., \& Mäenpää, P. (2010) Polyamines in cyanobacteria: biosynthesis, transport and abiotic stress response. Current research, technology and education topics in applied microbiology and microbial biotechnology. Formatex, Badajoz, 23-32.
Jancewicz, A.L., Gibbs, N.M., \& Masson, P.H. (2016) Cadaverine's Functional Role in Plant Development and Environmental Response. Front. Plant Sci. 7 https://doi:10.3389/fpls.2016.00870

Jham, G.N., Moser, B.R., Shah, S.N., Holser, R.A., Dhingra, O.D., Vaughn, S.F., Berhow, M.A., Winkler-Moser, J.K., Isbell, T.A., Holloway, R.K., Walter, E.L. Natalino. R., Anderson, J.C., Stelly, D.M. (2009) Wild Brazilian mustard (Brassica juncea L.) seed oil methyl esters as biodiesel fuel. J. Am. Oil Chem.' Soc. 86, 917-926. https://doi.org/10.1007/s11746-009-1431-2

Khan, M.R., Rashid, H., Qurgaishi, A. (2002) Effects of various growth regulators on callus formation and regeneration in Brassica napus cv. Oscar. Pak J Biol Sci. 5, 693-695. https://doi.org/10.3923/pjbs.2002.693.695

Klimaszewska, K., Keller, W.A. (1985) High frequency plant regeneration from thin cell layer explants of Brassica napus. Plant Cell Tiss Org. 4:183-197. https://doi.org/10.1007/BF00040193

Kott, L.S. (1998) Application of doubled haploid technology in breeding of oilseed Brassica napus. AgBiotech News and Information. 10, 69-74 https://doi.org/10.1533/9781908818478.183

Laemmli, U.K. (1970) Cleavage of structural protein during the assembly of head of bacteriophage T4. Nature. 227, 680-685.

Lima, G.P.P., Piza, I.M.T., Henrique, A., Takaki, M. (2003) Polyamines as salinity biochemical marker in callus of Eucalyptus urograndis. Ciência Florestal. 13(1), 43-48. https://doi.org/10.5902/198050981722

Lowry, J.H., Rosenbrough, N.J., Fair, A.L., Randall, R.J. (1951) Protein measurement with the foline phenol reagent. J. Biochem. 193, 265-275.

Ma, W., Chen, K., Li, Y., Hao, N., Wang, X., and Ouyang, P. (2017) Advances in Cadaverine Bacterial Production and Its Applications. Engineering, 3(3), 308 317. https://doi:10.1016/j.eng.2017.03.012

Moreau, P.L. (2007) The Lysine Decarboxylase Cad A Protects Escherichia coli Starved of Phosphate against Fermentation Acids. J. Bacteriol. 189(6), 2249 2261. https://doi:10.1128/jb.01306-06

Murashige, T., Skoog, F. (1962) A revised medium for rapid growth and bioassays with tobacco cultures. Physiol. Plant. 15, 473-497. https://doi.org/10.1111/j.1399-3054.1962.tb08052.x

Niemi, K., Häggman, H., Sarjala, T. (2002) Effects of exogenous diamines on the interaction between ectomycorrhizal fungi and adventitious root formation in Scots pine in vitro. Tree Physiol. 22, 373-381. https://doi.org/10.1093/treephys/22.6.373

Rajpal, C. \& Tomar C.P. (2020) Cadaverine: A potent modulator of plants against abiotic stresses. J. microbiol., biotechnol. food sci. 10(2), 205-210.

Rodríguez, C., de Armas, R., Vicente, C., \& Legaz, M.E. (2000) Changes in free and conjugated polyamines during starvation of sugarcane juices as analyzed by high-performance liquid chromatography. J. Chromatogr. A. 881(1-2), 531-541. https://doi:10.1016/s0021-9673(00)00207-7

Rolen, S.H., Sorensen, P.W., Mattson, D., Caprio, J. (2003) Polyamines as olfactory stimuli in the gold fish Carassius auratus. J Exp Biol. 206, 1683-1696. https://doi.org/10.1242/jeb.00338

Samartzidou, H., Mehrazin, M., Xu, Z., Benedik, M.J., \& Delcour, A.H. (2003) Cadaverine Inhibition of Porin Plays a Role in Cell Survival at Acidic pH. $J$. Bacteriol. 185(1), 13-19. https://doi:10.1128/jb.185.1.13-19.2003

Sempruch, C., Leszczyński, B., Wójcicka, A., Makosz, M., Matok, H., \& Chrzanowski, G. (2010) Changes in activity of lysine decarboxylase in winter triticale in response to grain aphid feeding. Acta Biol Hung. 61(4), 512-515. https://doi:10.1556/abiol.61.2010.4.13

Shirata, K., Takagishi, H. (1990) Salt-induced accumulation of 26 and $27 \mathrm{kD}$ proteins in cultured cells of rice plant. J. Soil Sci. 36 (1), 153-157. https://doi.org/10.1080/00380768.1990.1041572110.

Singh, N.K., Braken, C.A., Hasegawa, P.M., Handa, A.K., Buckel, S. Hermodson, M.A., Pfankoch Regnier, F.E., Bressan, R.A. (1987) Characterization of osmotin: a thaumatin-like protein associated with osmotic adaptation in plant cells. Plant Physiol. 85, 529-536. https://doi.org/10.1104/pp.85.2.529

Strohm, A.K., Vaughn, L.M., Masson, P.H. (2015) Natural variation in the expression of ORGANIC CATION TRANSPORTER 1 affects root length responses to cadaverine in Arabidopsis. J. Exp. Bot. 66, 853-862 https://doi.org/10.1093/jxb/eru444

Tomar, P.C., Lakra, N., Mishra, S.N. (2013a) Effect of cadaverine on Brassica juncea (L.) under multiple stresses. Indian J. Exp. Biol. 51(9), 758-763.

Tomar, P.C., Lakra, N., Mishra, S.N. (2013b) Cadaverine: a lysine catabolite involved in plant growth and development. Plant Signal Behav. 8 (10), e25850 https://doi.org/10.4161/psb. 25850

Zheng, M.Y., Konzak, C.F. (1999) Effect of 2,4-dichlorophenoxyacetic acid on callus induction and plant regeneration in anther culture of wheat (Triticum aestivum L.). Plant Cell Rep. 19, 69-73. https://doi.org/10.1007/s002990050712 